\title{
ARISTOTELIAN THEORIES IN ABRAHAM IBN EZRA'S COMMENTARIES TO THE BIBLE*
}

\author{
MARIANO GÓMEZ ARANDA \\ ILC-CSIC, MADRID
}

\begin{abstract}
Some of Abraham ibn Ezra's philosophical ideas exposed in his biblical commentaries are the same as those of Aristotle. The purpose of this article is to analyse some of the Aristotelian ideas appearing in Abraham ibn Ezra's biblical commentaries and explain how he adapts the Aristotelian concepts to the explanation of the specific biblical verses. Ibn Ezra uses these concepts in his explanation of the structure of the Universe as found in some Psalms, the creation of the world in Genesis 1, and the origin of evil according to the book of Ecclesiastes. This paper also attempts to provide a hypothesis on how Ibn Ezra was able to apprehend Aristotelian philosophy.
\end{abstract}

Key Words

Aristotle, philosophy, astrology, medieval science, Bible exegesis.

The philosophical ideas of Abraham ibn Ezra (c. 1089-c. 1161) are not contained in specific philosophical treatises, but included in numerous comments and remarks scattered throughout his many diverse writings, mainly in his biblical commentaries, astrological works and theologian treatises.

Abraham ibn Ezra is often characterized as one of the earliest representatives of Neoplatonism in medieval Jewish philosophy, although it is more precise to situate him within some of the larger intellectual currents of his day in the process of reconciliation of Greek philosophy with Jewish tradition. As Howard Kreisel has pointed out, medieval Jewish and Islamic thinkers of the Middle Ages

* This article is part of the project 'Science and Religion in Judaism in Medieval Iberia' (FFI201675230-P) financed by the Ministerio de Economía y Competitividad of Spain. 
tended to combine 'Neoplatonism' with 'Aristotelian' conceptions in a variety of ways. ${ }^{1}$ In this sense, 'eclecticism' should be a more precise term to define medieval 'Neoplatonic' philosophy. Some of Ibn Ezra's philosophical ideas can only be understood on the basis of the appropriation and transmission of Aristotelian philosophy in medieval times.

The purpose of this article is to analyse some of the Aristotelian ideas appearing in Abraham ibn Ezra's biblical commentaries and explain how he adapts the Aristotelian concepts to the explanation of the specific biblical verses. This paper also attempts to provide a hypothesis on how Ibn Ezra was able to apprehend Aristotelian philosophy. The question to what extent his Aristotelianism is mixed with Neoplatonism is beyond the limits of this article.

Although Abraham ibn Ezra never cites Aristotle in his biblical commentaries, the Greek philosopher is cited in his astrological writings. In the second version of his Book of Reasons, Ibn Ezra refers to him as 'the wise Greek'. In the first version of this book, Ibn Ezra refers to Aristotle's De Anima as a source on which he drew to learn about some astrological aspects of the animal soul. ${ }^{2}$

As Steven Harvey affirms, before Maimonides and Abraham Ibn Da'ud in the second half of the twelfth century, there is little sign that most of Aristotle's major writings were carefully studied by Jewish authors. ${ }^{3}$ In this sense, Abraham ibn Ezra's use of Aristotelian ideas marks one of the earliest stages in the integration of Aristotle's philosophy in the Jewish thought.

\section{The Structure of the Aristotelian Cosmos}

One of Ibn Ezra's commentaries in which the influence of Aristotelian theories is more evident is his commentary on Psalm 148. ${ }^{4}$ Ibn Ezra affirms that this psalm is very honored, for it contains very deep secrets. The concept of 'secrets' in Ibn Ezra's thought means that Biblical texts contain hints or allusions to scientific matters. ${ }^{5}$ According to him, this psalm speaks of the existence of two worlds: the

1 Howard Kreisel, 'On the Term Kol in Abraham Ibn Ezra: A Reappraisal', Revue des Études Juives 153 (1994), pp. 29-66, at p. 33.

2 Shlomo Sela, Abraham ibn Ezra and the Rise of Medieval Hebrew Science, Leiden-Boston: Brill, p. 174, n. 70.

3 Steven Harvey, 'The Greek Library of the Medieval Jewish Philosophers', in Cristina D'Ancona (ed.), The Libraries of the Neoplatonists. Proceedings of the Meeting of the European Science Foundation Network 'Late Antiquity and Arabic Thought. Patterns in the Constitution of European Culture', Leiden: Brill, 2007, pp. 493-506, at p. 501.

4 For the Hebrew text of Ibn Ezra's commentary on Psalms, see Menachem Cohen (ed.), Mikra'ot Gedolot 'Haketer'. Psalms. A Revised and Augmented Scientific Edition of 'Mikra'ot Gedolot' Based on the Aleppo Codex and Early Medieval Mss., 2 vols, Ramat-Gan: Bar Ilan University Press, 2010.

5 Miriam Sklarz, 'Ibn Ezra's Secrets in Nachmanides' Commentary: Affinities in Terminology and Exegetical Contexts', in Michael Avioz, Elie Assis and Yael Shemesh (eds), Zer Rimonim: Studies in 
upper world, which is described as wide and big; and the lower world, which is defined as the imaginary point at the centre of the big circle. The lower world is thus the earth and the upper world is the rest of the Universe.

Even the structure of the psalm represents, according to Ibn Ezra, such a division: the first part of the psalm (verses 1-6) deals with the upper world; the second part (verses 7-14) with the lower world.

Moreover, Ibn Ezra finds in the order of the verses of the first part of the psalm, the order of the heavenly beings in the upper world from the highest to the lowest. The psalm begins mentioning the angels (Ps. 148:2), those that have no body, below them all his host (Ps. 148:2) is placed. According to Ibn Ezra, the expression all his host are pure bodies, not composed of the four elements; they refer to all the fixed stars placed in the sphere of constellations. ${ }^{6}$ Below them, the Sun and the Moon, explicitly mentioned in the psalm (Ps. 148:3), are placed. According to Ibn Ezra, the Sun and the Moon in the psalm are representative of all of the seven planets. In order to justify why only these two among the seven planets are mentioned in the psalm, he explains that they are considered $h a-$ moshelim (the dominants), the planets that exert more influences on the earthly beings than the rest of the planets. They are called in the psalm the shining stars, because they both have a stronger light than the rest of the planets for they are close to the earth.

Below the Sun and the Moon, the highest heavens (Ps. 148:4) are placed. Ibn Ezra finds in this expression an allegory to the sphere or circle of fire which is below the Moon. Below the sphere of fire, the waters above the heavens are placed. Ibn Ezra finds in this expression a reference to the sphere of rain (ha-sagrir). ${ }^{7} \mathrm{He}$ finishes the description of the first part of Psalm 148 by saying, 'this is the limit of the superior world.'

In the second part of Psalm 148 (verses 7-14), according to Ibn Ezra, the earthly beings are mentioned in an order contrary to the heavenly beings: the heavenly beings are placed from the highest to the lowest, but the earthly beings are mentioned from the lowest-the sea monsters, mentioned in verse 7-to the highest-the people of Israel, the highest people in rank, mentioned in verse 14.

Biblical Literature and Jewish Exegesis Presented to Professor Rimon Kasher, Atlanta: Society of Biblical Literature, 2013, pp. 503-523; Shaul Regev, 'Ta'amei Ha-Mitzvot in R. Avraham Ibn Ezra's Commentary: Secrets', in Fernando Díaz Esteban (ed.), Abraham Ibn Ezra y su tiempo. Actas del Simposio Internacional, Madrid: Asociación Española de Orientalistas, 1990, pp. 233-240; Hannah Kasher, 'Ibn Kaspi's Commentary to the Secrets of Ibn Ezra', in Moshe Hallamish (ed.), 'Alei Shefer. Studies in the Literature of Jewish Thought Presented to Rabbi Dr. Alexandre Safran, Ramat-Gan: Bar Ilan University Press, 1990, pp. 89-108.

6 Sela, Abraham ibn Ezra and the Rise, pp. 218-219.

7 In Psalm 104:3, the expressions the upper chambers in the waters and the clouds also refer, according to our author, to the sphere of rain. 
In his commentary on Psalm 148, Ibn Ezra reproduces the Aristotelian structure of cosmos: a great sphere divided into an upper and lower region by the spherical shell in which the moon is situated. Above the moon is the celestial region; below is the terrestrial region with the four elements of nature placed in the following order: fire, air, water and earth. The terrestrial or sublunary region is the world of generation and corruption and of transient changes of all kinds; the celestial or superlunary realm, by contrast, is a region of eternally unchanging cycles.

Ibn Ezra, however, does not represent the Aristotelian cosmos exactly as the Greek philosopher described it, but he introduces some changes for exegetical reasons to fit with the meaning of the biblical verses. Ibn Ezra includes the angels in the upper world for they are explicitly mentioned in the psalm.

For exegetical reasons, Ibn Ezra affirms that the limits of the upper world are from the angels to the sphere of rain, which is below the sphere of fire, which is below the sphere of the Moon. The sphere of rain corresponds to the sphere of water in the Aristotelian cosmos, and belongs to the sublunary world, as the other three spheres of the elements fire, air and earth. Ibn Ezra, however, considers that the universe is divided into two regions, the lower region is only the earth and everything that it contains, and the upper region is formed by the spheres of the other three elements-water, air, and fire, in this order-, the sphere of the Moon and those of the other planets, the sphere of the fixed stars, and the celestial world of angels.

According to Ibn Ezra, the expression He (God) established them forever and ever (Ps. 148:6) means that the heavenly beings are eternal and unchangeable, because they are pure bodies, not composed of the four elements, and therefore not subject to generation and corruption. It is a clear reference to the eternity of the Universe. The expression He set a law that cannot pass away (Ps. 148:6) refers to the eternal law that regulates the motions of the planets: each planet has a specific orbit around which he circles the earth and, since its motion is cyclical, it never ends.

The Aristotelian idea that the planets and stars are not composed of the four elements, but of a fifth element, is repeated several times by Ibn Ezra in his astrological treatises and in his biblical commentaries. ${ }^{8}$ In his long commentary on Exod. 33:21, Ibn Ezra affirms:

Do not think that the four elements are in heaven and that there is heat in the Sun and coldness in the Moon and Saturn. Heaven forbid. The creations that are high

8 For his astrological treatises, see, for example, Abraham ibn Ezra, The Book of Reasons. A Parallel Hebrew-English Critical Edition of the Two Versions of the Text by Shlomo Sela, Leiden-Boston: Brill, 2007, pp. 34-35, 120, 184-185, and 268. See also Sela, Abraham ibn Ezra and the Rise, pp. 255, and $370-371$. 
Aristotelian Theories in Abraham Ibn Ezra's Commentaries to the Bible

and above are glorious. Scripture says concerning them, for He commanded and they were created (Ps. 148:5), He established them forever and ever; He set a law that cannot pass away (Ps. 148:6). They were created in this way only because of those whom they affect. ${ }^{9}$

According to Ibn Ezra, the heavenly bodies were created only to have the effects hot and dry, and cold and wet on earth, but they were not created as natural properties of themselves. Thus, the Sun is said to be hot and dry only because it produces these effects on the earth.

Following Aristotle, Ibn Ezra sustains that the heavenly bodies are neither made out of the four sublunary elements nor inherently possess the natural and physical properties of sublunary bodies, but they have the ability of generating astrological influence, thereby affecting the corresponding natural and physical properties of sublunary bodies.

What Ibn Ezra wants to prove is that the biblical text of Psalm 148 describes the structure, composition and laws of the Universe according to the principles of Aristotelian cosmology. Even the order of the verses of the psalm and the heavenly beings mentioned in them are parallel to the heavenly beings in the Aristotelian cosmos. Ibn Ezra follows Aristotle in one of the most controversial ideas in medieval Jewish philosophy: the eternity of the Universe.

\section{The creation of the world}

The influence of Aristotelian cosmological doctrines is also present in Ibn Ezra's comments on the creation of the world. He wrote at least two commentaries on Genesis, the first one in Lucca, between 1142 and 1145, and the second one in Rouen, between 1155 and $1156 .{ }^{10}$

The most relevant point in Ibn Ezra's both commentaries on the creation of the world, according to Genesis 1, is that the creation described in this biblical text does not refer to the entire universe, but only to the formation of the firmament and the earth. In Aristotelian terms, creation in Genesis only refers to the sublunary world and it must be understood from an earthly point of view. ${ }^{11}$

9 Abraham Ibn Ezra, Perushe ha-Torah, ed. Asher Weizer, Jerusalem: Mosad Harav Kook, 1976, vol. II, p. 218. For the English translation, Abraham ibn Ezra, Commentary on the Pentateuch: Exodus (Shemot), trans. and annot. H. Norman Strickman and Arthur M. Silver, New York: Menorah, 1996, pp. 700-701.

10 On this chronology, see Shlomo Sela and Gad Freudenthal, 'Abraham Ibn Ezra's Scholarly Writings: A Chronological Listing', Aleph 6 (2006), pp. 13-55.

11 For the Hebrew text, see Abraham Ibn Ezra, Perushe ha-Torah, vol. I, pp. 11-19, 147-149. For an English translation of the second commentary, see Abraham ibn Ezra, Commentary on the Pentateuch: Genesis (Bereshit), trans. and annot. H. Norman Strickman and Arthur M. Silver, New York: Menorah, 1988, pp. 21-48. For an analysis of Ibn Ezra's commentaries on creation, see 
According to our author, the word heaven in Genesis 1:1 refers only to 'the heaven visible to human beings', that is, the firmament. Ibn Ezra explicitly affirms that 'in my opinion, the heaven and the earth spoken of in our verse refer only to the firmament and the dry land.'

The meaning of the first two verses of Genesis, according to Ibn Ezra's interpretation, is: 'When the creation of the firmament and the dry land took place, the earth was in chaos because it was covered with water.' Ibn Ezra then adds that 'God created the earth in such a way that by the laws of nature it would be below the waters.' (commentary on Gen 1:2). Ibn Ezra's expression 'by the laws of nature' must be understood here as equivalent to 'according to Aristotle's natural philosophy.' In the Aristotelian cosmos, the earth is placed immediately below the sphere of the elemental water. Thus the first verses describe, in Ibn Ezra's opinion, the primordial state of the sublunary world, with earth and water as the primeval elements, which were the starting point of subsequent meteorological processes.

According to Ibn Ezra, the expression God's wind swept over the face of the waters (Gen 1:2) means that 'the wind was the medium employed by God to dry the land.'

In his first commentary on And God said: "Let there be a firmament in the middle of the waters, and let it separate waters from waters" (Gen 1:6), Ibn Ezra explains that this verse demonstrates how the firmament was created: "the firmament is the air, because when the light shone very strongly upon the earth and a wind dried the earth, the flame turned into the firmament.' According to Ibn Ezra, light plays a relevant creative role in the process of the formation of the world.

In his second commentary on this same verse, Ibn Ezra is more precise in the description of the coming-to-be of the firmament: the earth was covered by water, the wind dried the water over the earth, and the earth was visible. Ibn Ezra cites Gen 8:1 to prove that the same action happened at the end of the flood, when God made a wind which blew over the earth and dried the waters. Ibn Ezra continues by affirming the following:

The firmament, which is the atmosphere that is above the earth, exists because of the light. When the light of the Sun touches upon the earth, it returns upwards because of the thickness of the earth and thus the air which is contact with the earth is heated.

Shlomo Sela, 'La creación del mundo supralunar según Abraham Ibn Ezra: un estudio comparativo de sus dos comentarios a Génesis 1,14', Sefarad 63 (2003), pp. 147-181 and Tamás Visi, 'The Early Ibn Ezra Supercommentaries: A Chapter in Medieval Jewish Intellectual History', Ph.D. Diss., Central European University, Budapest, 2006, pp. 151-159. 
The light is the means that creates the firmament by reflecting on the Earth and returning from it, thus heating the atmosphere that is placed between the Sun and the Earth. The natural phenomena described in Genesis did not take place by the direct action of the divine power, but by natural causes commanded by the divine power. Ibn Ezra explains this point as follows:

Scripture describes creation as coming about by God's word, because it wants to teach us that the heaven and the earth came into being without any labour on God's part. We may compare this to a king assigning certain tasks to his servants. (Commentary on Gen 1:3)

Following Aristotle's Meteorology, Ibn Ezra provides a naturalistic explanation of the creation: God did not do any labour, He simply commanded the elements of nature to change themselves and become the different parts of the world: the earth, the firmament, and everything that is contained in them.

With what phenomena of nature spoken of in Aristotle's Meteorology should we identify Ibn Ezra's explanations? In Meteorology I.4 we read:

When the sun warms the earth the exhalation which takes place is necessarily of two kinds, not of one only as some think. One kind is rather of the nature of vapour, the other of the nature of a windy exhalation. That which rises from the moisture contained in the earth and on its surface is vapour, while that rising from the earth itself, which is dry, is like smoke. Of these the windy exhalation, being warm, rises above the moister vapour, which is heavy and sinks below the other. ${ }^{12}$

According to Aristotle, the region close to the earth is the host-moist region. It is the region in which the air is mixed with the moist exhalation that ascends from the sea. This region is hot because it is warmed by the rays of the sun that strike the earth and return from it to the lower part of the air.

Ibn Ezra's explanations of the creation of the firmament according to the biblical text are based on Aristotle's Meteorology: by a combination of the actions of the wind and the light that was created on the first day of creation, the water covering the earth was transformed into the air of the atmosphere, and the firmament was created.

Isaac Abravanel (1437'1508) was one of the first authors in the Middle Ages who saw a clear influence of Aristotle's Meteorology on Abraham ibn Ezra's interpretation of the creation of the firmament. Abravanel criticised fiercely Ibn Ezra's point of view:

12 Aristotle, The Complete Works, ed. Jonathan Barnes, Princeton: Princeton University Press, 1984, p. 559, $341 \mathrm{~b}$. 
When he was stirred by the topic of the firmament, Abraham Ibn Ezra wrote that the appearance of the dry land was the cause for the generation of the firmament, [...] because in this he was drawn after the view of the Philosopher in the Meteorology. [...] But the words of the Philosopher [suppose] that nature runs its course, because they [the philosophers] had no conception of the creation of the world. But the words of Abraham Ibn Ezra, of whom we said: 'under his shadow we shall live' (Lam. 4:20) in explaining the Torah-see how far they have retreated from the truth of the Torah in denying the story of the Creation. ${ }^{13}$

Abravanel considers that, by being influenced by Aristotle, Ibn Ezra was as a defender of the idea of eternity of the world, and for this reason he criticizes him.

Abraham Ibn Ezra also considers that the text describing the creation of the world in Genesis 1 is parallel to that of Psalm 104. According to his interpretation, in psalm 104, King David describes the creation of the world in consonance with the description of Genesis 1. The first thing that was created was light, mentioned first in the psalm in the expression You [referring to God] are wrapped in light as with a garment (Ps. 104:2), then the other elements in the world such as the firmament and the earth are created by the action of the light. As the word heaven in the text of Genesis, Ibn Ezra explicitly mentions that the heavens in the expression You stretch out the heavens like a tent (Ps. 104:2) are the firmament on which there is water, fire, snow and wind. Therefore, the firmament is the atmosphere, where the meteorological phenomena of nature occur. Also as in the text of Genesis 1, Ibn Ezra explicitly mentions that the earth in the expression You set the earth on its foundations (Ps. 104:5) refers to the dry land.

In addition to this, Ibn Ezra wants to demonstrate that Psalm 104 recognizes that wind and fire played an active part in the creation of the world. The expression You make the winds your messengers, fire and flame your ministers (Ps. 104:4) proves that wind and fire were used by God as his active agents to create the world. Also as in the case of Genesis 1, the creation of the world was not performed by God himself, but by the elements of nature, which, by God's commands, acted as agents to become the different parts of the world.

According to Abraham Ibn Ezra, Genesis 1 and Psalm 104 describe the creation of the world according to the principles of the elements of nature contained in Aristotle's Meteorology. The wind and the light of the Sun played an important role in the process of creation, because through their cation the water was transformed into the atmosphere and the dry land appeared.

13 Isaac Abravanel, Commentary on the Torah: Genesis, Jerusalem: Benei Arbel, p. 47a. For the English translation, see Aviezer Ravitzky, 'Aristotle's Meteorology and the Maimonidean Modes of Interpreting the Account of Creation', Aleph 8 (2008), pp. 361-400 (p. 371). 


\section{The laws of nature}

Abraham ibn Ezra wrote his commentary on the book of Ecclesiastes (or Qohelet, in Hebrew) in Rome in $1140 .{ }^{14}$ It is the first biblical commentary he ever wrote in his life. It is preceded by an introduction, in which Ibn Ezra explains one of the most relevant ideas of the biblical book: the origin of evil in the world.

Ibn Ezra writes that 'the origin of evil is in the imperfection of the recipient'. To clarify this idea, Ibn Ezra uses an analogy:

We observe that clothes spread out in the sun are bleached while the launderer's face turns black. But should not one cause have one effect? The effects are different because the natures of the recipients are different.

According to Ibn Ezra, the recipients here are material created beings, which 'receive' and are affected by certain powers and influences from the superior world. Ibn Ezra uses here the Hebrew word toledet, normally translated as 'nature', to refer to the combinations of the four elements-earth, water, air and fire-which form the nature of earthly beings. ${ }^{15}$ Ibn Ezra means to say that, since the combination of the elements is different in each earthly being, each one has an innate natural disposition to be affected by the influence of the superior beings. Ibn Ezra thereby drives to the point that evil was not created by God, but is rather a natural consequence of the materiality of the earthly beings.

Ibn Ezra goes on to mention several kinds of these influences on human beings:

The thoughts of human beings vary depending on the temperaments of their respective bodies; and these temperaments vary depending on the changes in the heavenly configurations, in the position of the sun, in that which receives its influences, and in states, laws, and foods.

As a consequence of such a variety of influences-Ibn Ezra suggests-, all human misfortunes, calamities, and miseries in this world have a natural cause, namely, the imperfect nature of created human beings.

Ibn Ezra concludes his introduction by focusing on the uselessness of human actions. If all human actions depend on the influence of the heavenly beings, everything that we do in this world is vanity and makes no profit. This is precisely, according to Ibn Ezra, the meaning of the book of Ecclesiastes: it states

14 For the Hebrew text and a Spanish translation of this commentary, see Abraham Ibn Ezra, El Comentario de Abraham Ibn Ezra al libro del Eclesiastés, ed. Mariano Gómez Aranda, Madrid: CSIC, 1994.

15 On the use of the term toledet by Ibn Ezra, see Sela, Abraham Ibn Ezra and the Rise, pp. 130-137 and Abraham Ibn Ezra, The Book of Reasons, pp. 115 and 387. 
a scientific verity that there is no profit in all works done under the sun. Is there any worthwhile activity in this world? Ibn Ezra affirms that 'the works of human beings are emptiness and vanity, except for the fear of God.' Here Ibn Ezra arrives to the same conclusion as the book of Ecclesiastes: nothing makes sense, except the fear of God.

The influence of heavenly on earthly beings is implied in several of Aristotle's statements in some of his works, and specially in his Meteorology:

The whole world surrounding the earth, the affections of which are our subject, is made up of these bodies (meaning, the four elements). This world necessarily has a certain continuity with the upper motions; consequently all its power is derived from them. [...] We must treat fire and earth and the elements like them as the material causes of the events in this world-meaning by material what is subject and is affected-, but must assign causality in the sense of originating principle of motion to the power of the eternally moving bodies (Meteorology I.2) ${ }^{16}$

According to Ibn Ezra, the book of Ecclesiastes is a book dealing with the laws of nature, that is, with Aristotelian natural science. In his explanation of the first verses of Ecclesiastes, Ibn Ezra wants to prove that the biblical text conforms to the rules of natural science.

The verse what has been is what will be, and what has been done is what will be done; there is nothing new under the sun (Eccl. 1:9) is interpreted by Ibn Ezra as follows:

What has been refers to the spheres and their hosts, because they are like wheels turning constantly around, and their beginning is like their end and their end like their beginning. What has been done is what will be done refers to the genera which are preserved, like the human species, the equine species, and every animal and vegetable species, the generation of which depends on the motions of the heavenly bodies. If the heavenly bodies are eternal, so also are the genera, because they are structured by the celestial configurations. The meaning is that although I cannot count the individual, the genera persist, are known, and can be counted. In this way, it is seen that upper and lower worlds persist in the same manner and there is nothing new under the sun. ${ }^{17}$

The most important question posed in the biblical text is why it is said that there is nothing new under the sun. To respond to such a question, Ibn Ezra makes use of the rules of natural science in an attempt to prove that the biblical text conforms to them.

Mutations in the physical beings are constant, cyclical and perpetual. The generation process owes these characteristics to the intervention of a cause

16 Aristotle, The Complete Works, pp. 555-556, 339a.

17 Abraham Ibn Ezra, El Comentario, pp. $14^{*}-15^{*}$ and 21-22 (Spanish translation). 
Aristotelian Theories in Abraham Ibn Ezra's Commentaries to the Bible

external to the mutable things themselves. This external cause is the heavens and the celestial bodies, whose nature and motion are unchanging and uniform. In other words, the heavenly bodies, composed of a fifth element and in perpetual motion as a natural result of their constitution, exert their influence unceasingly. Generation and corruption therefore are cyclical and perpetual in the physical world, thus paralleling the perpetuity of the moving cause.

Ibn Ezra also explains here the Hebrew word ha-kelalim, which literally means 'principles,' 'general principles' or 'general entities.' In this context ha-kelalim is a technical term referring to 'species.' According to his explanation, the fixicity of species in the world depends on the fixed stars. In consequence, when the Bible affirms what has been done is what will be done is in fact reproducing the scientific theory that the species of earthly beings will always be the same for they depend on the heavenly beings which are unchangeable.

Ibn Ezra's explanations on Eccl. 1:9 reproduce the Aristotelian principles in his book De generatione et corruptione (On Generation and Corruption). According to Aristotle, 'circular motion, that is, the revolution of the heavens, is eternal' and eternal motion is the cause of generation:

Since the change which is motion has been proved to be eternal, the continuity of coming-to-be follows necessarily from what we have established; for the eternal motion, by causing the generator to approach and retire, will produce coming-tobe uninterruptedly. [...] God [...] fulfilled the perfection of the universe by making coming-to-be uninterrupted. [...] That coming-to-be should itself come-to-be perpetually is the closest approximation to eternal being. The cause of this is circular motion, for that is the only motion which is continuous. (De generatione II.10) ${ }^{18}$

According to Aristotle, generation, understood as the transformation of the elements of nature into another, is continuous, and in consequence, as the text of Ecclesiastes says, there is nothing new under the sun.

Another scientific explanation based on Aristotelian thought is given by Ibn Ezra in his comments on all streams run to the sea, but the sea is not full; to the place where the streams flow, there they continue to flow (Eccl. 1:7):

Although all the streams flow into the sea, it does not overflow, so as to transgress the law and cover the earth, because the waters which flow into it return constantly to their own place, for there is evaporation constantly rising from the sea to the sky, and this evaporation forms the clouds. Only the sweet waters ascend because of their lightness, and the vapour is converted into rain, as is written He (referring to God) calls for the waters of the sea, and pours them out on the surface of the earth (Amos 5:8). The waters of the springs are from the rain,

18 Aristotle, The Complete Works, pp. 550-552, 336a-337a. 
and the streams are from the springs, as we see in time of drought that most of the springs are dried up. This explains how the streams return again from the place to which they went. ${ }^{19}$

Ibn Ezra's observations are very similar to the explanations given by Aristotle in Meteorology II.13 on the origin of rivers:

The water is raised by the sun and descends in rain and gathers below the earth and so flows from a great reservoir, all the rivers from one, or each from a different one. No water at all is generated, but the volume of the rivers consists of the water that is gathered into such reservoirs in winter. Hence rivers are always fuller in winter than in summer, and some are perennial, others not. Rivers are perennial where the reservoir is large and so enough water has collected in it to last out and not be used up before the winter rain returns. Where the reservoirs are smaller there is less water in the rivers, and they are dried up and their vessel empty before the fresh rain comes on. ${ }^{20}$

Ibn Ezra's explanations also reflect the influence of Aristotle's explanations in Meteorology II.3 on why the sea is salty: the sun dries up the sweet water and raises it up through evaporation. By condensation, the sweet water is transformed into clouds and descends to the earth in rain. Aristotle then adds:

The sea is there and some of it is continually being drawn up and becoming sweet; this returns from above with the rain. But it is now different from what it was when it was drawn up, and its weight makes it sink below the sweet water. This process prevents the sea, as it does rivers, from drying up except from local causes (this must happen to sea and rivers alike). On the other hand, the parts neither of the earth nor of the sea remain constant but only their whole bulk. For the same thing is true of the earth as of the sea: some of it is carried up and some comes down with the rain, and both that which remains on the surface and that which comes down again change their situations. ${ }^{21}$

According to Abraham ibn Ezra, the book of Ecclesiastes reproduces the laws of nature, that is, the laws of Aristotelian natural science. By these laws, the origin of evil in this world-one of the most relevant ideas in the biblical text-can be explained: it was not created by God, but it is a natural consequence of the imperfect nature of the earthly beings, which makes them vulnerable to the influence of the heavenly beings.

\footnotetext{
Abraham Ibn Ezra, El Comentario, pp. 12*-13* and 18-19 (Spanish translation).

Aristotle, The Complete Works, p. 570, 349b.

Ibid., pp. 582-583, 358b.
} 
Aristotelian Theories in Abraham Ibn Ezra's Commentaries to the Bible

The sounds of stars

Abraham Ibn Ezra not always agrees with Aristotle on all the characteristics of the heavenly beings. He disagrees with the Aristotelian theory that the heavenly bodies produce no sound. In De Caelo II.9, Aristotle rejects the Pythagorean idea that stars emit pleasant sounds:

From all this it is clear that the theory that the movement of the stars produces a harmony, i.e. that the sounds they make are concordant, in spite of the grace and originality with which it has been stated, is nevertheless untrue. Some thinkers suppose that the motion of bodies of that size must produce a noise, since on our earth the motion of bodies far inferior in size and in speed of movement has that effect. Also, when the sun and the moon, they say, and all the stars, so great in number and in size, are moving with so rapid a motion, how should they not produce a sound immensely great? ${ }^{22}$

In his attempt to provide a rational explanation on the verse More majestic than the sounds of mighty waters... is the Lord (Ps. 93:4), Abraham ibn Ezra finds in the expression the sounds of mighty waters a reference to the idea that the motion of the celestial spheres produces mighty sounds: 'this [verse] is an indication that spheres produce sounds.' He then cites the verse I heard the sounds of their wings like the sound of mighty waters (Ezek. 1:24) as a proof that the expression the sound of mighty waters refers allegorically to the sound of the spheres, as in the case of Psalm 93:4. Ezekiel perceived the sound of the wings of the creatures in the chariot as the sound of the celestial spheres.

Ibn Ezra also adds, that 'those unable to hear these sounds are deaf, in the same manner as those who are unable to see the deeds of God are blind. ${ }^{23}$ Hearing and seeing in this context should be interpreted as characteristics of intelligent human beings. As Ibn Ezra explains in his commentary on Isaiah 42:18, 'hearing and seeing originate in the heart: those that are deaf and blind in their hearts are, therefore, called here deaf and blind. ${ }^{24}$ Therefore, Ezekiel was able to perceive the sounds of the spheres as he was an intelligent human being, capable of perceiving the extraordinary phenomena created by God in the celestial realm. ${ }^{25}$

\footnotetext{
Ibid., p. 479, 290 b.

Sela, Abraham Ibn Ezra and the Rise, p. 309, n. 196.

Abraham Ibn Ezra, The Commentary of Ibn Ezra on Isaiah, ed. Michael Friedländer, London: Society for the Promotion of Hebrew Literature, 1873, pp. 72 and 191 (translation).

25 This is one of the few references to the account of the chariot in Ibn Ezra's commentaries; for other references to this biblical passage in Ibn Ezra's works, see Howard Kreisel, 'From Esotericism to Science: The Account of the Chariot in Maimonidean Philosophy Till the End of
} 
In Guide 2:8, Maimonides deals with the controversy between Aristotle and the Pythagorean philosophers on the possibility of celestial sounds. Maimonides interprets that the sages in the Talmud are in favor of the Pythagorean notion that the motion of stars in heaven produces sound. Some Jewish philosophers like Samuel Ibn Tibbon, Gersonides, Joseph Ibn Kaspi, Moses Narboni and Profiat Duran, in interpreting Maimonides' explanations on the celestial sounds, arrive to the conclusion that Ezekiel ascribes sounds to the celestial spheres. ${ }^{26}$ The existence of the same idea in Abraham ibn Ezra's comments on Psalm 93:4 proves that they might have been influenced by this author.

\section{Abraham Ibn Ezra's Aristotelian sources: a hypothesis}

How could have Ibn Ezra become acquainted with Aristotelian natural science? As is well known, he lived in al-Andalus from 1089 until 1140, then moved to Italy and spend the rest of his life until he died in 1165 travelling through Italy, France and England. Most probably he knew Aristotelian theories through some of the works of Aristotelian philosophers and scientists that he might have known while living in al-Andalus. ${ }^{27}$

I will now take into consideration Avicenna and Abu Ma'shar as the most possible channels through which Ibn Ezra had access to Aristotelian knowledge. A detailed analysis of the connections between Ibn Ezra and Avicenna and Abu Ma'shar goes beyond the limits of this article. However, I formulate my hypothesis based on the similarities between Ibn Ezra's explanations in his biblical commentaries studied above and some of the Aristotelian theories exposed by Avicenna and Abu Ma'shar.

\section{Ibn Ezra and Avicenna}

The connections between Avicenna and Aristotelian philosophy have been widely studied by Dimitri Gutas. ${ }^{28}$ That Abraham Ibn Ezra knew Avicenna's works is proved by the fact that Ibn Ezra's Hay ben Mekitz is an adaptation of Avicenna's

the Thirteenth Century', in James T. Robinson (ed.), The Cultures of Maimonideanism: New Approaches to the History of Jewish Thought, Leiden-Boston: Brill, 2009, pp. 21-56 (pp. 31-33).

26 Charles Touati, 'Le problème de l'inerrance prophétique dans la théologie juive du Moyen Age', Revue de l'histoire des religions 174 (1968), pp. 169-187 (pp. 180-182); see also Ofer Elior, 'Ezekiel Is Prefereable to Aristotle: Torah and Science in Four Interpretations of Ezekiel's 'I Heard", Pe'amim 139-140 (2014), pp. 55-80 [Hebrew]. On Samuel Ibn Tibbon's interpretation of Ezekiel's perception of celestial sounds, see Kreisel, 'From Esotericism', pp. 48-49.

27 For Abraham Ibn Ezra's life, see Israel Levin, Abraham Ibn Ezra. His Life and His Poetry, Tel Aviv: Hakibbutz Hameuchad, 1969 [Hebrew].

28 Dimitri Gutas, Avicenna and the Aristotelian Tradition: Introduction to Reading Avicenna's Philosophical Works, Leiden-Boston: Brill, 2014. 
Aristotelian Theories in Abraham Ibn Ezra's Commentaries to the Bible

Hayy ibn Yaqzan. As Aaron W. Hughes noted, Ibn Ezra's Hay follows the structure of Avicenna's Hayy and, in terms of the characters and the plot, both works are almost identical. ${ }^{29}$ According to some modern scholars, Avicennian theories are present in some of Ibn Ezra's interpretations of the biblical text, especially in Ibn Ezra's interpretation of God as the Necessary Existent in the first of the Ten Commandments ${ }^{30}$ and in his exegesis on the account of creation. ${ }^{31}$ Resianne Fontaine has also pointed out that Abraham ibn Ezra's ideas that the imperfection of the recipient is the origin of evil and that it is not fitting for superior wisdom to preclude the greater good because of small evil, as stated in his commentary on Ecclesiastes, are similar to Avicenna's conception of evil as privation and as something that is found only in the sublunary world due to the existence of matter. ${ }^{32}$

The influence of Avicenna on Abraham ibn Ezra was already suggested by some medieval scholars. In Guadalajara in 1370, Samuel ibn Motot wrote a work entitled Meguillat Setarim, which is in fact a super-commentary on Abraham ibn Ezra's commentaries on the Torah. ${ }^{33}$ In his introduction, Samuel ibn Motot affirms the following:

Ibn Ezra's opinions are like those of Aristotle's and in the secret of creation he followed Avicenna. For this reason, his words are hidden and his secrets are marvellous. ${ }^{34}$

29 For a comparison between Ibn Ezra's Hay ben Mekitz and Avicenna's Hayy ibn Yaqzan, see Aaron W. Hughes, The Texture of the Divine: Imagination in Medieval Islamic and Jewish Thought, Bloomington-Indianapolis: Indiana University Press, 2004. There are, however, major differences between these two works, as exposed by Aaron W. Hughes, 'A Case of TwelfthCentury Plagiarism? Abraham Ibn Ezra's Hay Ben Meqitz and Avicenna's Hayy Ibn Yaqzan', Journal of Jewish Studies 55 (2004), pp. 306-331.

30 Warren Z. Harvey, 'The First Commandment and the God of History: Halevi and Crescas Vs. Ibn Ezra and Maimonides', Tarbiz 57 (1988), pp. 203-216 [in Hebrew] and Steven Harvey, 'Avicenna's Influence on Jewish Thought: Some Reflections', in Y. Tzvi Langermann (ed.), Avicenna and His Legacy: A Golden Age of Science and Philosophy, Turnhout: Brepols, 2009, pp. 327-340, esp. p. 329.

31 Gad Freudenthal and Mauro Zonta, 'Avicenna among Medieval Jews: The Reception of Avicenna's Philosophical, Scientific and Medical Writings in Jewish Cultures, East and West', Arabic Sciences and Philosophy 22 (2012), pp. 217-287, esp. p. 254.

32 Resianne Fontaine, "'Happy Is He Whose Children Are Boys": Abraham Ibn Daud and Avicenna on Evil', In Dag Nikolaus Hasse and Amos Bertolacci (eds), The Arabic, Hebrew and Latin Reception of Avicenna's Metaphysics, Berlin-Boston: Walter de Gruyter, 2012, pp. 159-175, at p. 164.

33 On super-commentaries of Abraham Ibn Ezra's commentaries, see Uriel Simon, 'Interpreting the Interpreter: Supercommentaries on Ibn Ezra's Commentaries', in Isadore Twersky and Jay M. Harris (eds), Rabbi Abraham Ibn Ezra: Studies in the Writings of a Twelfth-Century Jewish Polymath, Cambridge, Massachusetts-London: Harvard University Press, 1993, pp. 86-128.

34 Samuel Ibn Motot, Meguillat Setarim, Venice 1553, p. 1 b. 
Samuel ibn Tibbon wrote his Maamar Yiqqavu ha-Mayim in Provence in the 1220s. In this book, Ibn Tibbon gives a scientific interpretation of the creation of the world, which, at some points, resembles the explanations given by Ibn Ezra. Ibn Tibbon's interpretation, however, is much more detailed. ${ }^{35}$

As Ibn Tibbon explains, the creation of the world as exposed in Genesis 1, deals with a situation in which the entire surface of the earth was covered by water. By God's command, Let the waters... be gathered... so that dry land may appear (Gn. 1:9), water moved out of its primordial natural place so that dry land emerged.

As in the case of Ibn Ezra, Ibn Tibbon attributes a primordial role to light in the process of creation. Ibn Tibbon also cites Psalm 104:2 to prove that the light was the first physical entity to appear. The ray of light that came to be on the first day is the first cause that the earth ceased to be in a state of chaos, that is, entirely covered by water. The light produced heat, which caused the evaporation of water and produced the firmament. After affirming that this information is found in several biblical and rabbinical texts, Ibn Tibbon adds: all these texts 'agree with what has been described by Avicenna'. ${ }^{36}$

In a sermon on the unity (al-Khuțbat al-gharra $\vec{a})$ delivered by Avicenna on the praise of God, Avicenna attributes light a significant role in the creation of physical forms. After speaking on the qualities of nature, heat, cold and moisture, Avicenna continues by saying:

You created Heat expanding in its essence, Cold contracting in its qualities, Moisture for preserving the bodies from being decomposed. From these [qualities] You created the primal elements, and the hottest of them You have stationed on the higher places (i.e. the heavens) which, were it Cold, would have been heated by the heavenly motion and no being had remained but perished, on account of the Heat spread over all the elements in potentiality and space. You created the higher [heavenly] elements (i.e. Fire, Air, Water) naturally transparent, otherwise no luminous ray could have passed through them. You created the Earth dustcoloured, otherwise the light, which is the cause of the Instinctive Heat, active in creating physical forms, would not have paused over it [but would have passed through]. So You created from the Earth, minerals, vegetables, and animals of different kinds, which became generator and corruptor, begetter and begotten. ${ }^{37}$

35 On a detailed analysis of Samuel Ibn Tibbon's explanations on creation, see Gad Freudenthal, 'Samuel Ibn Tibbon's Avicennian Theory of an Eternal World', Aleph 8 (2008), pp. 41-129.

36 Samuel Ibn Tibbon, Ma'amar Yiqqawu Ha-Mayim, ed. Mordecai Loeb Bisliches, Pressburg: Anton Edlen v. Schmid, 1837, p. 133.

37 Seyyed Hossein Nasr, An Introduction to Islamic Cosmological Doctrines, Cambridge, Massachusetts: Harvard University Press, 1964, pp. 208-209. 
In Physics 3:12, Avicenna explains how the Sun causes evaporation during its motions. Also in this work, Avicenna deals with the question of the alteration and transformation of the elements into one another 'in that very same region that is proper to its whole'. As a consequence-Avicenna explains-, air, while in the region of air, might undergo alteration so as to become rain or water, or, conversely, large quantities of water, while in the region of water, might be heated so as to become steam, or air. ${ }^{38}$

Avicenna's ideas on the role of light in the creation of physical beings and on the transformation of the elements of nature into one another served Ibn Ezra to interpret the creation of the world as described in the biblical texts. It may be possible that through the knowledge of these Avicennian theories, Ibn Ezra became acquainted with Aristotle's meteorological doctrines.

As Mauro Zonta affirms, before 1150, there are very few references to Avicenna by Jewish philosophers, although he was not totally unknown by some of them. Traces of Avicenna's philosophy can be found in Yehudah Halevi' Book of the Khazar and Joseph Ibn Saddiq's Microcosm. ${ }^{39}$ Since Abraham Ibn Ezra left alAndalus in 1140, he is one of the first Jewish authors to have became acquainted with Avicennian thought. Ibn Ezra could have known his works during his formation in al-Andalus or through his close relationship with Yehudah Halevi.

\section{Ibn Ezra and Abu Ma'shar}

Abraham Ibn Ezra's knowledge of Aristotle may also have come from Abu Ma'shar, the most important authority in astrology in the Muslim world. ${ }^{40} \mathrm{Ibn}$ Ezra mentions Abu Ma'shar in his Liber de rationibus tabularum as one of the magistri probationum, and also in his Keli ha-Nehoshet (Treatise of the astrolabe). The influence of Abu Ma'shar is especially relevant in Ibn Ezra's Sefer ha-'Olam (The Book of the World), where he is considered as the most important authority in astrological matters referring to the history and future of the nations of the world, and specifically in the astrological implications of the conjunctions of Jupiter and Saturn.

Abu Ma'shar's Introduction to Astrology, written in Baghdad in 848 was well known in al-Andalus in Ibn Ezra's times. In fact, it was translated into Latin by John of Seville in 1133. Ibn Ezra may have coincided with John of Seville during his wanderings in al-Andalus, visiting Toledo and Seville, among other cities,

38 Avicenna, The Physics of the Healing. A Parallel English-Arabic Text, trans. and annot. Jon McGinnis, Provo, Utah: Brigham Young University Press, 2009, vol. II, pp. 371-379.

39 Mauro Zonta, 'Avicenna in Medieval Jewish Philosophy', in Jules Janssens and Daniel de Smet (eds) Avicenna and His Heritage: Acts of the International Colloquium, Louvain: Leuven University Press, 2002, pp. 267-279 (pp. 267-268)

40 I am very grateful to Shlomo Sela, from Bar-Ilan University in Israel, for this suggestion. 
before leaving the country in $1140 .{ }^{41}$ In fact, it has been suggested that Abraham Ibn Ezra and John of Seville were working closely together. ${ }^{42}$ Through John of Seville, Ibn Ezra may have had access to the original Arabic text of Abu Ma'shar's Introduction.

As proved by Richard Lemay, Abu Ma'shar's Introduction to Astrology contains many characteristic features of Aristotelian physics and cosmology, and its influence of the intellectuals in the Middle Ages marked the starting point of the medieval interest in Aristotelian science, cosmology and even metaphysics. ${ }^{43}$

A relevant part of this work is an attempt at a scientific justification of astrology by the use of Aristotle's natural philosophy. For Abu Ma'shar, astrology is a valid science rooted in the principles of natural science and proved by experimentation.

As an astrologer, Abraham ibn Ezra was very interested in Abu Ma'shar's use of Aristotelian doctrines to justify the validity of astrology.

Many points in common can be found between Abu Mashar's explanations and Ibn Ezra's interpretations of some biblical verses, specially those dealing with astrological matters in his commentary on Ecclesiastes.

Abu Ma'shar based on Aristotle's natural philosophy to demonstrate the two principal premises of astrology: first, that the motions of the heavenly bodies are the source of all activity in the physical universe; and second, that the bodies of the inferior world have an innate disposition to receive such influences which are the causes of their own motions. ${ }^{44}$ The same ideas are exposed by Ibn Ezra in his introduction to his commentary on Ecclesiastes as well as in his own commentary on Ecclesiastes 1:9 (see above).

Abu Ma'shar also explained that although the motions of the planets are in themselves natural and uniform, they nevertheless present a great variety of possible combinations. Such varieties of influences are received by the elements of nature in the sublunary world. Whenever out of these combinations of influences a suitable and perfect result occurs, we understand that the planets have acted favourably, and the elements fully responded. However, when reluctant and unwilling nature is prevailed, we conclude that the planets acted unfavourably. ${ }^{45}$ These ideas are the base for Ibn Ezra's explanations on the origin of evil as stated in his introduction of his commentary on Ecclesiastes.

41 For this period of Abraham Ibn Ezra's life, see Levin, Abraham Ibn Ezra, pp. 14-15.

42 Charles Burnett, 'John of Seville and Limia', in Charles Burnett and Pedro Mantas España (eds), 'Ex Oriente Lux': Translating Words, Scripts and Styles in Medieval Mediterranean Society, CórdobaLondon: Universidad de Córdoba-The Warburg Institute, 2016, pp. 11-17 (p. 12).

43 Richard Lemay, Abu Mashar and Latin Aristotelianism in the Twelfth Century: The Recovery of Aristotle's Natural Philosophy through Arabic Astrology, Beirut: American University of Beirut, 1962, pp. 41-132.

$44 \quad$ Ibid., p. 49.

45 Ibid., pp. 97-98. 
Basing on Aristotle's Physics, Abu Ma'shar also explained that the circular motion of the superior bodies surrounding the world and circling it move the terrestrial bodies. The perfect motion is the cause of the imperfect one. This motion is a force originating in the superior bodies and reaching down to the bodies of the inferior world. The terrestrial bodies receive such action from the superior bodies because they are linked to them by the bond of their native disposition. ${ }^{46}$ These ideas are the basis of Ibn Ezra's explanations of the first verses of the book of Ecclesiastes.

Following Aristotle, Abu Ma'shar states that the nature of the superior beings is of a different kind than that of the four elements, and concludes that the celestial sphere and the planets were made of a fifth essence. ${ }^{47}$ This is precisely the interpretation of Ibn Ezra in his commentary on Psalm 104 and in other several exegetical and astrological contexts.

These connections between Ibn Ezra and Abu Ma'shar are sufficient to lead us to the conclusion that Abu Ma'shar's Introduction to Astrology was one of the main sources through which Ibn Ezra had access to Aristotelian doctrines.

\section{Conclusions}

Abraham ibn Ezra uses the Aristotelian structure of the universe divided in the superlunary and sublunary worlds to explain the structure and the contents of the Psalm 148. For exegetical reasons, Ibn Ezra adapts the Aristotelian division to the structure of this psalm. According to Ibn Ezra, the first part of the psalm (verses 1-6) represents the heavenly beings of the upper world in decreasing order. The second part of the psalm (verses 7-14) represents the earthly beings of the lower world in ascending order. Ibn Ezra uses Psalm 148:6 to prove that, according to the Bible as well as to Aristotelian philosophy, the heavenly beings are eternal because they are made of a fifth element; the earthly beings, however, are subject to generation and corruption for they are composed of the four elements of nature. Ibn Ezra follows Aristotle in defending the idea of the eternity of the Universe.

The influence of Aristotle's Meteorology is relevant in Ibn Ezra's comments on the Creation of the world as described in Genesis 1 and in Psalm 104 as well. According to Ibn Ezra, the creation in Genesis 1 refers only to the creation of the firmament and the dry land. This was a natural process in which the air, acting as a God's agent, dried the water that was covering the earth. By the action of the light, created on the first day of creation, the water covering the earth was heated, evaporation was produced and the atmosphere was created. These

\footnotetext{
Ibid., p. 62.

Ibid., pp. 58-59, 92-93.
} 
interpretations are based on Aristotle's descriptions of the phenomenon of the evaporation of water by the action of the sun in his Meteorology.

Aristotelian theories on the influence of heavenly beings on earthly beings are used by Ibn Ezra in his introduction to his commentary on Ecclesiastes and in his explanation of some verses from this biblical book. According to Ibn Ezra, this book deals with the laws of nature, that is, with Aristotelian natural science. Everything that happens in this world, the world of generation and corruption, depends on the eternal circular motions of the heavenly beings.

Not always Abraham Ibn Ezra agrees with the Greek philosopher in scientific matters. Against Aristotle, Ibn Ezra defends the idea that the motion of the spheres in heaven produces sounds. Basing on this concept, he explains that in the vision of the chariot, prophet Ezekiel was able to perceive the sound of the wings of the creatures he saw as the sound of celestial spheres, as he was an intelligent man. It is possible that Ibn Ezra have known this principle in Aristotle's criticism to the Pythagoreans in De Caelo.

Abraham ibn Ezra may have become acquainted with Aristotelian theories through Avicenna in the case of the theories on the creation of the world and through Abu Ma'shar in the case of the astrological explanations.

In my opinion, Abraham ibn Ezra's ultimate goal in using Aristotelian theories in his biblical commentaries is not only to prove that the Bible can be explained according to Aristotle, but also to demonstrate that the scientific Aristotelian theories can be found in the Bible, and that, in consequence, the study of Aristotle is legitimized by the sacred book. 